\title{
AKSES INTERNET DALAM KELUARGA HUBUNGANNYA DENGAN STATUS IMUNISASI DASAR LENGKAP ANAK BADUTA (ANALISIS DATA SDKI 2017)
}

\section{Internet Acces in Family and Its Relationship with The Complete Basic Immunization Status of Children Under Two Years (2017 IDHS Data Analysis)}

\author{
Olwin Nainggolan*, Felly Philipus Senewe \\ Puslitbang Upaya Kesehatan Masyarakat, Badan Litbangkes \\ JL Percetakan Negara 29 Jakarta Pusat, 10560, Indonesia \\ *E-mail : olwin.n@gmail.com
}

Naskah masuk 1 September 2020; review 1 September 2019; disetujui terbit 29 Desember 2020

\begin{abstract}
Background:Internet access penetration in Indonesia is growing, all information can be obtained very easily, including how the child's immune system can be obtained against diseases that can be prevented by immunization. However, the internet can also have a bad impact, because it is very easy to use to spread false news or hoaxes.

Objective: An analysis will be conducted to find the relationship between internet access in the family and the status of completeness of basic immunization for children under two years

Method: The study will use data from the Indonesian Health Demographic Survey (IDHS) conducted in 2017. The unit of analysis is children under two years. The analysis of the relationship between internet access in the family and the completeness status of basic immunization for children under two years used logistic regression analysis with a complex sample mode.

Result: The analysis shows that families in Indonesia who have internet access based on the 2017 IDHS data are 46.0 percent, and children under two years with complete basic immunization status is 65.3 percent. It can be seen that there is a relationship between internet access and the completeness status of basic immunization for children with OR 1.37 (1.14-1.66).

Conclusion: The internet is like a double-edged sword, one side can be used to find various information that is beneficial to health, but can also be used to spread false information. Therefore it is important to educate all Indonesians to use internet access positively.
\end{abstract}

Keywords: immunization, vaccine, IDHS, Indonesia.

\section{Abstrak}

Latar belakang: Penetrasi akses internet di Indonesia semakin berkembang, semua informasi dapat diperoleh dengan sangat mudah, termasuk bagaimana diperolehnya kekebalan tubuh anak terhadap penyakit-penyakit yang dapat dicegah dengan imunisasi. Akan tetapi, internet juga bisa memberikan dampak yang tidak baik karena sangat mudah dimanfaatkan untuk menyebarkan berita yang tidak benar atau hoax.

Tujuan: Akan dilakukan analisis untuk mencari hubungan antara akses internet dalam keluarga terhadap status kelengkapan imunisasi dasar anak bawah dua tahun.

Metode: Penelitian akan menggunakan data Survei Demografi Kesehatan Indonesia (SDKI) yang dilakukan tahun 2017. Unit analisis adalah anak bawah dua tahun (baduta). Analisis hubungan antara akses internet dalam keluarga dengan status kelengkapan imunisasi dasar anak bawah dua tahun menggunakan analisis regresi logistik dengan mode kompleks sampel.

Hasil: Analisis memperlihatkan bahwa keluarga di Indonesia yang memiliki akses internet berdasarkan data SDKI 2017 adalah sebesar 46,0 persen, dan baduta dengan status imunisasi dasar lengkap adalah sebesar 65,3 persen. Terlihat adanya hubungan antara akses internet dengan status kelengkapan imunisasi dasar anak dengan OR 1,37 (1,14-1,66).

Kesimpulan: Internet bagai pedang bermata dua, satu sisi dapat digunakan untuk mencari berbagai informasi yang bermanfaat bagi kesehatan, akan tetapi bisa juga dapat digunakan untuk menyebarkan informasi yang tidak benar. Oleh sebab itu, edukasi penting bagi seluruh penduduk Indonesia untuk menggunakan akses internet dengan positif.

Kata kunci: imunisasi, vaksin, internet, SDKI, Indonesia 


\section{PENDAHULUAN}

Internet telah merevolusi bagaimana cara informasi dibagikan dan diakses. Pencarian informasi lebih mudah diperoleh dibandingkan dengan sebelumnya. Sejak munculnya mesin pencari modern (search engine) dan jejaring sosial, akses informasi bisa diperoleh di mana saja melalui perangkat seperti smartphone, tablet, dan atau komputer, sehingga informasi tersedia setiap saat dan sepanjang hari. Salah satu domain penting peran internet adalah akses informasi kesehatan yang semakin meningkat. Tujuh puluh persen penduduk Kanada online untuk mencari informasi yang berkaitan dengan medis atau yang berhubungan dengan kesehatan. ${ }^{1}$ Selain itu, dilaporkan pula bahwa internet merupakan sumber informasi pertama bagi banyak orang. ${ }^{2}$ Aliran informasi telah berubah secara dramatis, sehingga mengakibatkan semakin berkurangnya peranan dokter atas informasi kesehatan yang disampaikan kepada pasien. Tidak mengherankan, pergeseran paradigma ini telah menimbulkan pandangan yang beragam dan terkadang bertentangan tentang nilai internet sebagai alat untuk meningkatkan pelayanan kesehatan. ${ }^{3}$

Vaksin adalah salah satu pencapaian di bidang kesehatan masyarakat yang sangat penting dalam sejarah manusia yang mengakibatkan penurunan signifikan berbagai penyakit khususnya penyakit menular pada anak-anak. ${ }^{4}$

Namun demikian, fenomena antivaksinasi $i^{5}$ dan keragu-raguan terhadap kemanfaatan vaksin, ${ }^{6,7}$ resistensi dan penolakan terhadap vaksin ${ }^{8}$, bisa membahayakan apa yang telah dicapai sejauh ini yaitu peluang munculnya kembali penyakitpenyakit menular disertai dengan wabah.

Sepuluh tahun terakhir, kontroversi tentang manfaat dan keamanan vaksin telah menjadi topik pembicaraan dan mendorong keprihatinan orang tua, media, pembuat kebijakan. ${ }^{9,10}$ Meskipun dampak imunisasi terhadap kesehatan telah terbukti, pemberian vaksin masih disertai dengan timbulnya

*Korespondensi:

(olwin.n@gmail.com)

CBadan Penelitian dan Pengembangan Kesehatan

ISSN: 2354-8762 (elektronik); ISSN: 2087-703X (cetak) kecemasan. ${ }^{11}$ Pertumbuhan pesat internet dan media sosial seperti Twitter dan Facebook telah menyebabkan informasi lebih mudah untuk disebarluaskan dengan segala macam bentuk, termasuk informasi terkait imunisasi. Namun juga sebaliknya, informasi-informasi yang salah juga sangat mudah disebarluaskan sehingga menimbulkan salah persepsi di masyarakat. ${ }^{12}$

Popularitas media sosial telah diidentifikasi sebagai salah satu sebab meningkatnya kecemasan orangtua terhadap keamanan vaksin bagi anak-anak. Internet adalah salah satu alat yang penting bagi banyak orang untuk mencari informasi, dukungan layanan kesehatan, serta berbagi pengetahuan kesehatan, pendapat, dan pengalaman. ${ }^{13}$ Media sosial yang semakin popular menyebabkan masyarakat tidak lagi mencari informasi kesehatan dengan cara konvensional. ${ }^{14}$ Internet memungkinkan untuk berbagi pendapat dan informasi secara cepat, mengorganisir diri sendiri, menciptakan jejaring sosial, dan memberdayakan sekelompok orang dengan mengusung tema antivaksin. ${ }^{15}$ Adanya sentimen antivaksinasi yang cukup besar telah menyebabkan orang tua mencari dan saling berbagi informasi tentang imunisasi. ${ }^{16}$ Sebuah studi yang meneliti tingkat kepercayaan orang tua terhadap vaksin di Amerika Serikat menemukan bahwa orang tua yang menolak vaksin atau yang menerima vaksin, masih memiliki sejumlah pertanyaan, masalah, atau mispersepsi tentang vaksin..$^{12,17}$

Banyaknya media online dan media sosial memberikan akses kemudahan dalam memberikan masukan, kritik, maupun saran dalam segala bidang. Banyak sekali pengguna media sosial yang memanfaatkan media ini untuk hal-hal yang sifatnya negatif dan dapat merugikan semua pihak, baik itu bagi pemerintah maupun masyarakat itu sendiri. Permasalahan yang timbul dari penggunaan media sosial saat ini adalah mudahnya hoax yang menyebar luas, bahkan orang terpelajar pun tidak bisa membedakan antara berita yang benar, advertorial, dan hoax. ${ }^{18}$ Kemajuan dunia internet tidak hanya di dunia Internasional, 
tetapi juga sampai ke Indonesia. Hasil survei penetrasi dan perilaku pengguna internet di Indonesia yang dilakukan oleh Asosiasi Penyelenggara Jasa Internet Indonesia (APJII) pada tahun 2017 menyatakan bahwa penetrasi pengguna internet di Indonesia adalah sekitar 54,68 persen atau setara dengan 143,26 juta jiwa dari 262 juta jiwa seluruh penduduk Indonesia. ${ }^{19}$ Dengan tingkat penetrasi internet demikian, tentunya semakin memudahkan penyebaran informasi terkait dengan pentingnya melakukan vaksinasi pada anak.

Pemberian vaksinasi pada anak, selain memberikan kekebalan terhadap penyakit tertentu, namun dapat juga memberikan efek yang lebih besar karena bisa mencegah penularan penyakit kepada anak yang lain. Drop out saat imunisasi dasar mengurangi efektivitas imunisasi dalam menimbulkan kekebalan dan melindungi bayi dan anak dari penyakit-penyakit yang dapat dicegah dengan imunisasi (PD3I). Keadaan seperti ini dengan sendirinya akan mengurangi keberhasilan program imunisasi secara keseluruhan. Imunisasi dapat dikatakan berhasil bila bayi atau anak telah memperoleh seluruh vaksinasi yang diwajibkan, sebagai imunisasi dasar. Banyaknya informasi yang menyesatkan tentang keamanan vaksin bertebaran di media sosial. Ditambah lagi dengan isu tentang kehalalan vaksin yang beredar di Indonesia. Terdapat berbagai faktor penyebab masyarakat di Indonesia tidak memberikan imunisasi kepada anak, utamanya adalah adanya anggapan bahwa vaksin yang digunakan untuk imunisasi haram karena mengandung bahan yang kehalalannya diragukan. ${ }^{20}$

Dengan latar belakang demikian, semua bentuk informasi yang diperoleh, selain dapat memberikan pemahaman baru kepada orang tua tentang seluk beluk imunisasi yang diberikan pada seorang anak, tetapi juga dapat mempengaruhi niat orang tua untuk memberikan imunisasi pada anaknya atau tidak. Penelitian ini bertujuan untuk melihat hubungan antara akses internet penduduk Indonesia dengan status kelengkapan imunisasi dasar anak umur $12-23$ bulan. Peneliti berhipotesis bahwa orang tua yang memiliki akses internet memiliki peluang lebih banyak untuk memberikan vaksinasi kepada anak-anak mereka dibandingkan dengan orang tua yang tidak memiliki akses internet di Indonesia.

\section{BAHAN DAN METODE}

Unit analisis penelitian ini adalah anak di bawah dua tahun (baduta) yaitu umur 12 bulan sampai dengan 23 bulan. Anak bawah dua tahun yang memiliki riwayat imunisasi dan riwayat antenatal care (ANC) dilakukan merging dengan data umur serta riwayat pendidikan kepala keluarga. Data selanjutnya di-merging dengan data rumah tangga meliputi akses internet dalam keluarga, jumlah balita, wilayah tempat tinggal, serta status ekonomi keluarga. Status imunisasi dasar dikatakan lengkap jika baduta memperoleh seluruh imunisasi yang tercantum dalam Peraturan Menteri Kesehatan Republik Indonesia Nomor 12 tahun 2017 meliputi satu kali Hepatitis B (HB0), satu kali imunisasi Bacillus CalmetteGuérin (BCG), tiga kali imunisasi difteri, pertusis, dan Tetanus-Hepatitis B (DPT-HB), empat kali imunisasi polio, dan satu kali imunisasi campak. Imunisasi BCG diberikan pada bayi umur kurang dari tiga bulan, imunisasi polio pada bayi baru lahir, dan tiga dosis berikutnya diberikan dengan jarak paling cepat empat minggu; imunisasi DPT-HB pada bayi umur dua bulan; tiga bulan empat bulan dengan interval minimal empat minggu dan imunisasi campak paling dini umur sembilan bulan. ${ }^{21}$ Status imunisasi dasar tidak lengkap jika hanya diberikan sebagian dari jenis imunisasi dasar yang diwajibkan atau anak sama sekali tidak diberikan imunisasi seluruhnya. Keluarga disebut memiliki akses internet jika menggunakan internet minimal seminggu sekali. Pengelompokan umur didasarkan pertimbangan kombinasi sebaran data serta pengelompokan umur berdasarkan kategori umur menurut WHO. $^{22}$ Kategori jumlah anak dengan cut of 2 merupakan program Kependudukan, Keluarga Berencana, dan Pembangunan Keluarga (KKBPK). ${ }^{23}$ Tingkat pendidikan orang tua disebut dengan pendidikan tinggi jika mengaku pernah memperoleh pendidikan minimal Diploma, dan pendidikan rendah jika mengikuti jenjang Sekolah Menengah Atas (SMA) ke bawah. Status ekonomi diperoleh dari quintile indeks kepemilikan barang, disebut dengan tidak miskin jika rumah tangga masuk kategori quintile 3, 4, 5 dan masuk kategori miskin jika masuk quintile 1 dan quintile 2. Variabel Antenatal Care (ANC) K4 adalah pemeriksaan pada saat kehamilan ke dokter atau tenaga kesehatan terlatih (satu kali pemeriksaan pada 
saat kehamilan trimester pertama, satu kali pemeriksaan saat kehamilan trimester kedua, dan dua kali pemeriksaan pada saat kehamilan trimester ketiga). Penelitian menunjukkan bahwa pemeriksaan kehamilan (ANC) yang dilakukan di fasilitas kesehatan memberikan dampak terhadap ibu dalam memberikan imunisasi terhadap anaknya kemudian. Hal ini menunjukkan bahwa fasilitas kesehatan antenatal adalah platform konvensional untuk mendidik ibu hamil tentang manfaat imunisasi anak. $^{24}$

Tahap awal, analisis univariat dilakukan untuk melihat proporsi serta jumlah sampel yang telah dilakukan pembobotan semua variabel yang diikutsertakan dalam analisis meliputi: status imunisasi, akses internet dalam keluarga, kelompok umur orang tua, jumlah balita, tingkat pendidikan orangtua, status sosial ekonomi, serta wilayah. Jumlah sampel yang dianalisis adalah sebanyak 3633 anak yang merupakan jumlah total anak baduta survei SDKI tahun 2017 dan jumlah rumah tangga (ruta) yang memiliki anak baduta sebanyak 3570 ruta. Penelitian menggunakan kerangka konsep pendekatan model faktor risiko di mana status imunisasi baduta sebagai variabel dependen utama, dan akses internet dalam keluarga sebagai variabel independen utama. Sedangkan variabel kelompok umur orang tua, jumlah balita, tingkat pendidikan orangtua, status sosial ekonomi, serta wilayah tempat tinggal diperlakukan sebagai variabel perancu. Analisis regresi logistik berganda digunakan untuk menilai hubungan antara variabel independen utama, dalam hal ini akses internet dalam keluarga, dengan variabel dependen yaitu status imunisasi baduta. Analisis regresi logistik yang digunakan adalah regresi logistik model complex samples dengan mengikutsertakan variabel bobot yang sudah dirata-ratakan, Primary Sampling Unit (PSU), serta Strata. Jumlah N yang dihasilkan menggunakan analisis complex samples disebut dengan jumlah $\mathrm{N}$ tertimbang. Fungsi dari pembobotan adalah untuk menyamakan peluang yang diakibatkan pengambilan sampel pada SDKI 2017 bukan Simple Random Sampling (SRS) dan jumlah $\mathrm{N}$ tertimbang menjaga agar jumlah sampel yang telah dibobot sama dengan jumlah sampel pada survei.

\section{Limitasi Penelitian}

Akses internet dalam keluarga tidak selalu hanya digunakan untuk mencari informasi tentang manfaat imunisasi dan keamanan vaksin bagi anak-anak, tetapi pencarian informasi segala bidang. Sehingga, pendekatan yang digunakan adalah proxy keluarga yang memiliki akses internet, memiliki kecakapan dan kemampuan untuk pencarian informasi tentang vaksin dan imunisasi. Akses internet tidak harus dikuasai oleh orang tua bayi, tetapi bisa saja pada anggota rumah tangga lain yang tinggal dalam satu rumah. Penelitian ini tidak dirancang khusus untuk melihat akses internet dalam keluarga dan dampaknya langsung terhadap imunisasi anak baduta dalam keluarga, akan tetapi ada banyak faktor-faktor lain yang berpengaruh. Oleh sebab itu, untuk melihat pengaruh bersih akses internet, analisis ini mengikutsertakan variabel perancu lain yaitu: jumlah anak balita dalam keluarga, umur kepala keluarga, status sosial ekonomi, ANC K4 serta tempat tinggal responden berada di wilayah perkotaan atau perdesaan.

\section{HASIL}

Hasil analisis univariat pada Tabel 1 memperlihatkan karakteristik responden penelitian akses internet dalam keluarga dan hubungannya dengan status imunisasi dasar lengkap anak bawah dua tahun SDKI tahun 2017. Tabel 1 menunjukkan bahwa proporsi imunisasi dasar lengkap baduta berdasarkan data SDKI tahun 2017 adalah sebesar 65,3 persen, menurun sebesar 1 persen dibandingkan dengan proporsi imunisasi dasar lengkap baduta berdasarkan data SDKI tahun 2012 yaitu sebesar 66 persen. ${ }^{25}$ Proporsi keluarga yang memiliki akses internet di Indonesia masih cukup sedikit hanya sebesar 46 persen. Berdasarkan kelompok umur kepala keluarga, umur 45 tahun ke atas adalah kelompok umur yang paling banyak yaitu sebesar 38,9 persen, jauh lebih banyak dibandingkan dengan kelompok umur lainnya. Keluarga yang memiliki jumlah anak balita $\leq 2$ di Indonesia dengan proporsi paling besar yaitu sebanyak 95,8 persen. Sebanyak 36,9 persen latar belakang pendidikan kepala keluarga adalah SMA, proporsi paling tinggi dibandingkan dengan latar belakang pendidikan yang lain. Dari sisi status sosial ekonomi, proporsi kelompok tidak miskin lebih banyak sebesar 59,5 persen, dibandingkan dengan kelompok status sosial ekonomi miskin sebesar 40,5 
persen. Ibu yang melakukan pemeriksaan ANC K4 lengkap, mempunyai proporsi sebanyak 57,8 persen, lebih banyak dibandingkan dengan yang tidak melakukan pemeriksaan ANC K4 sebesar 42,2 persen. Responden yang tinggal di daerah perdesaan lebih banyak dibandingkan dengan yang tinggal di daerah perkotaan.

Tabel 1. Karakteristik Responden SDKI 2017 menurut akses internet terhadap status imunisasi baduta

\begin{tabular}{|c|c|c|c|}
\hline Variabel & N Terbobot & Persentase & $95 \% \mathrm{CI}$ \\
\hline \multicolumn{4}{|l|}{ Status Imunisasi Dasar } \\
\hline - Lengkap & 2323 & 65,3 & $63,1-67,5$ \\
\hline - Tidak Lengkap & 1233 & 34,7 & $32,5-36,9$ \\
\hline \multicolumn{4}{|c|}{ Akses Internet dalam keluarga } \\
\hline - $\quad \mathrm{Ya}$ & 1670 & 46,0 & $43,8-48,3$ \\
\hline - $\quad$ Tidak & 1958 & 54,0 & $51,7-56,2$ \\
\hline \multicolumn{4}{|c|}{ Kelompok Umur orang tua (Tahun) } \\
\hline$-<30$ & 422 & 11,6 & $10,3-13,3$ \\
\hline$-30-34$ & 600 & 16,5 & $15,0-18,1$ \\
\hline$-35-39$ & 660 & 18,2 & $16,7-19,7$ \\
\hline - $40-44$ & 536 & 14,8 & $13,3-16,4$ \\
\hline$-\geq 45$ & 1413 & 38,9 & $36,8-41,0$ \\
\hline \multicolumn{4}{|l|}{ Jumlah Anak Balita } \\
\hline$-\leq 2$ & 3340 & 95,8 & $94,9-96,5$ \\
\hline$->2$ & 147 & 4,2 & $3,5-5,1$ \\
\hline - $\quad$ Tinggi & 398 & 11,3 & $10,0-12,8$ \\
\hline - Rendah & 3120 & 88,7 & $87,2-90,0$ \\
\hline \multicolumn{4}{|l|}{ Status Sosial Ekonomi } \\
\hline - $\quad$ Tidak Miskin & 2160 & 59,5 & $57,0-61,9$ \\
\hline - $\quad$ Miskin & 1472 & 40,5 & $38,1-43,0$ \\
\hline \multicolumn{4}{|l|}{ ANC K4 } \\
\hline - $\quad Y a$ & 2101 & 57,8 & $55,7-60,0$ \\
\hline - $\quad$ Tidak & 1531 & 42,2 & $40,0-44,3$ \\
\hline \multicolumn{4}{|l|}{ Wilayah } \\
\hline - Perkotaan & 1773 & 48,8 & $46,9-50,7$ \\
\hline - Perdesaan & 1859 & 51,2 & $49,3-53,1$ \\
\hline
\end{tabular}

Tabel 2 memperlihatkan bahwa proporsi baduta dengan status imunisasi dasar lengkap pada keluarga dengan akses internet sebesar 69,7 persen, lebih tinggi dibandingkan dengan keluarga tanpa akses internet. Dari sisi kelompok umur kepala keluarga, proporsi status baduta dengan imunisasi dasar lengkap paling tinggi pada kelompok umur $35-30$ tahun. Meskipun demikian, proporsi tersebut tidak berbeda jauh dengan kelompok umur lainnya. Keluarga yang memiliki jumlah $\leq 2$ anak, status imunisasi dasar lengkapnya lebih tinggi dibandingkan dengan keluarga dengan jumlah $>2$ anak. Status imunisasi dasar lengkap sebesar 73,1 persen berasal dari kepala keluarga dengan latar belakang pendidikan tinggi, lebih banyak dibandingkan dengan kepala keluarga dengan pendidikan rendah sebesar 64,7 persen. Demikian juga orang tua yang berasal dari status ekonomi tidak miskin memiliki proporsi yang lebih tinggi yaitu sebesar 68,7 persen, dibandingkan yang berasal dari status ekonomi miskin, dengan proporsi imunisasi dasar lengkap sebesar 60,2 persen. Terdapat perbedaan sekitar 9 persen lebih tinggi anak dengan status imunisasi dasar lengkap, antara ibu yang melakukan pemeriksaan ANC K4 lengkap dengan ibu yang tidak melakukan pemeriksaan ANC K4 lengkap. Ibu yang tinggal di daerah perkotaan memiliki proporsi anak dengan imunisasi dasar lengkap lebih tinggi dibandingkan dengan ibu yang tinggal di daerah perdesaan. 
Tabel 2. Tabulasi silang antara variabel akses internet dalam keluarga dengan variabel Status imunisasi baduta (SDKI 2017)

\begin{tabular}{llrrrr}
\hline & \multirow{2}{*}{ Variabel } & \multicolumn{3}{c}{ Status Imunisasi Dasar Baduta } \\
\cline { 3 - 6 } & & \multicolumn{2}{c}{ Lengkap } & \multicolumn{2}{c}{ Tidak Lengkap } \\
\cline { 3 - 5 } & & $\mathbf{N}$ & $\mathbf{\%}$ & $\mathbf{N}$ & $\mathbf{\%}$ \\
\hline Akses Internet dalam & Ada & 1142 & 69,7 & 496 & 30,3 \\
keluarga & Tidak Ada & 285 & 69,1 & 127 & 30,9 \\
Kelompok Umur KK & $<30$ & 371 & 63,7 & 211 & 36,3 \\
(tahun) & $30-34$ & 427 & 66,2 & 218 & 33,8 \\
& $35-39$ & 330 & 63,0 & 194 & 37,0 \\
& $40-44$ & 908 & 65,4 & 480 & 34,6 \\
Jumlah Balita & $\geq 45$ & 2186 & 66,1 & 1123 & 33,9 \\
& $\leq 2$ & 76 & 52,8 & 68 & 47,2 \\
Tingkat Pendidikan & 285 & 73,1 & 105 & 26,9 \\
Keluarga & Kepala & 1985 & 64,7 & 1081 & 35,3 \\
Status Sosial Ekonomi & Tinggi & 1460 & 68,7 & 663 & 31,3 \\
& Rendah & 863 & 60,2 & 569 & 39,8 \\
ANC K4 & Tidak Miskin & 1440 & 69,2 & 642 & 30,8 \\
\multirow{2}{*}{ Wilayah } & Miskin & 883 & 59,9 & 591 & 40,1 \\
& Ya & 1151 & 66,3 & 586 & 33,7 \\
& Tidak & 1171 & 64,4 & 647 & 35,6 \\
\hline
\end{tabular}

Tabel 3 memperlihatkan variabel akses internet dalam keluarga dan seluruh variabel perancu kecuali variabel wilayah tempat tinggal, layak masuk ke dalam model multivariat akhir. Hasil analisis logistik berganda model akhir memperlihatkan bahwa akses internet dalam keluarga sangat berhubungan dengan status imunisasi dasar lengkap anak bawah dua tahun di Indonesia, setelah dikontrol oleh variabel perancu. Keluarga yang tidak memiliki akses internet memiliki risiko 1,37 (95\% CI 1,14 1,66) untuk memiliki anak dengan imunisasi dasar tidak lengkap, dibandingkan dengan keluarga dengan akses internet. Selanjutnya, yang menjadi variabel perancu dalam penelitian ini adalah jumlah anak balita dengan OR 1,51 (95\% CI 1,00 - 2,3), serta pemeriksaan ANC K4 (95\% CI $1,51-2,30)$.

Tabel 3. Analisis awal dan akhir analisis multivariat penelitian hubungan akses internet dalam keluarga dengan status imunisasi dasar lengkap (SDKI 2017)

\begin{tabular}{|c|c|c|c|c|}
\hline Variabel & $\begin{array}{c}\text { OR Crude } \\
\text { (95\% CI) } \\
\text { Model Awal }\end{array}$ & $P$ value & $\begin{array}{c}\text { OR Adj } \\
\text { (95\% CI) } \\
\text { Model akhir }\end{array}$ & $P$ value \\
\hline \multicolumn{5}{|c|}{ Akses Internet dalam } \\
\hline \multicolumn{5}{|l|}{ keluarga } \\
\hline $\mathrm{Ya}$ & Ref & & Ref & \\
\hline Tidak & $1,43(1,20-1,72)$ & 0,00 & $1,37(1,14-1,66)$ & 0,00 \\
\hline \multicolumn{5}{|c|}{ Jumlah Anak Balita } \\
\hline$\leq 2$ & Ref & & Reff & \\
\hline$>2$ & $1,74(1,15-2,62)$ & 0,01 & $1,51(1,00-2,3)$ & 0,05 \\
\hline \multicolumn{5}{|l|}{ Tingkat Pendidikan } \\
\hline \multicolumn{5}{|c|}{ Kepala Keluarga } \\
\hline Tinggi & Ref & 0,01 & & \\
\hline Rendah & $1,47(1,12-1,96)$ & & & \\
\hline \multicolumn{5}{|c|}{ Status Sosial Ekonomi } \\
\hline Tidak Miskin & Reff & 0,00 & & \\
\hline Miskin & $1,45(1,20-1,75)$ & & & \\
\hline \multicolumn{5}{|l|}{ ANC K4 } \\
\hline Ya & Reff & & Reff & \\
\hline Tidak & $1,50(1,25-1,80)$ & 0,00 & $1,51(1,00-2,30)$ & 0,00 \\
\hline
\end{tabular}




\section{PEMBAHASAN}

Hasil analisis menunjukkan bahwa prevalensi imunisasi dasar lengkap berdasarkan studi SDKI 2017 adalah sebesar 65,3 persen, turun sebanyak 0,7 persen dibandingkan dengan hasil studi yang sama yang dilakukan pada tahun 2012. Namun demikian, tidak serta merta dapat disimpulkan demikian karena point prevalensi tahun 2012 melewati 95\% Confidence Interval tahun 2017. Paling tidak, angka ini mengindikasikan bahwa cakupan imunisasi lengkap anak tidak ada perkembangan yang berarti dalam kurun waktu selama 5 tahun terakhir ini. Oleh sebab itu, perlu evaluasi terkait 'mandeknya' peningkatan cakupan imunisasi terhadap anak di Indonesia. Penelitian ini juga menunjukkan bahwa penetrasi internet di keluarga Indonesia masih sekitar 46 persen, belum mencapai setengah dari populasi seluruh keluarga di Indonesia. Walaupun demikian, terlihat bahwa cakupan imunisasi anak dengan status lengkap pada anak di keluarga yang punya akses internet relatif lebih tinggi dibandingkan dengan cakupan imunisasi lengkap pada keluarga tanpa akses internet. Hasil analisis statistik menggunakan regresi logistik membuktikan bahwa akses internet berhubungan sangat bermakna dengan status imunisasi dasar lengkap anak di keluarga Indonesia. Besaran risiko dengan OR sebesar 1,37(1,14-1,66), menunjukkan bahwa keluarga yang tidak memiliki akses internet berisiko 1,37 kali anaknya tidak imunisasi lengkap, dibandingkan dengan anak yang berasal dari keluarga memiliki akses internet setelah dikontrol oleh variabel perancu jumlah anak serta ibu melakukan ANC K4.

Lestari (2014) yang melakukan penelitian perilaku masyarakat Indonesia dalam penggunaan internet menyatakan penetrasi internet di Indonesia sebenarnya masih cukup rendah yaitu 46 persen, Ia menyatakan wilayah yang penggunanya paling sering mengakses internet di Indonesia adalah wilayah DKI Jakarta dengan proporsi 53,6 persen dengan mayoritas penggunaan internet adalah untuk membuka situs jejaring sosial Facebook, Twitter, Google+, Instagram. Jejaring sosial tidak hanya populer di wilayah DKI Jakarta, tetapi juga wilayah Papua, Maluku, Sulawesi, dan Sumatera mayoritas penggunaan internet adalah untuk media sosial. Penggunaan internet untuk belajar banyak dilakukan oleh pengguna internet di Pulau Kalimantan. Pulau Jawa, sebanyak 6,3 persen pengguna bermain game sebagai aktivitas utama. Pulau Bali merupakan wilayah dengan proporsi internet untuk kepentingan e-commerce dengan proporsi 22,4 persen dan menerima serta mengirim email sebanyak 15,4 persen. ${ }^{26}$

Bila dibandingkan dengan negara lain, misalnya Kanada melaporkan bahwa 80 persen penduduk Kanada berusia lebih dari 16 tahun menggunakan internet, ${ }^{1}$ di mana 64 persen dari pengguna internet ini mencari informasi terkait medis atau kesehatan. Facebook dilaporkan sebagai platform media sosial paling populer. Lebih dari setengah populasi login ke Facebook setidaknya sekali dalam sebulan dan tingkat penggunaannya lebih tinggi dibandingkan ratarata global dan Amerika Serikat. ${ }^{27,28}$ Mayoritas orang tua dilaporkan mencari informasi terkait keamanan vaksin sebelum memvaksinasi anakanak mereka dan mengidentifikasi internet sebagai sumber informasi penting. ${ }^{17}$ Di Belanda, sebanyak 45,8 persen para orang tua menilai tidak cukup informasi yang diterima dari Program Imunisasi Nasional dan secara aktif mencari informasi tambahan. ${ }^{29}$ Sebuah studi cross-sectional yang dilakukan oleh Bianco dan rekannya di Italia menyatakan 29,6 persen orang tua Italia mencari informasi tentang vaksinasi dari internet. ${ }^{30}$ Pencarian informasi terkait vaksinasi di web dapat berdampak positif pada kemauan untuk menerima vaksinasi. ${ }^{31}$ Penelitian yang dilakukan oleh Barak-Corren dan Reis di Israel menunjukkan bahwa kegiatan yang berhubungan dengan pencarian informasi di internet adalah proksi kepatuhan vaksinasi. ${ }^{32}$

Internet telah menjadi sumber informasi utama di abad ke-21 di mana setiap orang memiliki akses dalam segala aspek mencari informasi di ujung jari. Beberapa penelitian menunjukkan banyak orang tua memperoleh informasi mengenai vaksinasi melalui sumber internet. Hal ini menjadi tantangan dengan begitu banyaknya informasi yang tersedia untuk mengetahui informasi mana yang akurat dan dapat diandalkan. ${ }^{33}$ Beberapa penelitian yang dilakukan tentang bagaimana informasi ditemukan di internet mempengaruhi keputusan orang tua tentang apakah anak akan divaksinasi atau tidak. Hal ini dikarenakan internet adalah sumber informasi yang sangat luas di mana 
studi-studi yang pernah dilakukan menggunakan pendekatan dari berbagai aspek. Beberapa studi berfokus hanya pada jenis vaksin tertentu, sedangkan yang lain lebih umum. Selain itu ada juga penelitian dengan target media online tertentu. ${ }^{34}$

Di satu sisi, meluasnya penyebaran kontenkonten tentang vaksin tidak hanya mampu meningkatkan basis audiens potensial terkait informasi berbasis internet, namun di sisi lain hampir mustahil untuk mengatur serta melakukan pembatasan dari sudut pandang normatif. Meskipun luas dan melimpah, informasi yang tersedia di internet terkadang tidak selalu dapat diandalkan. ${ }^{35}$ Lebih jauh, banyak informasi berbasis internet yang dijangkau orang tua tentang vaksin yang justru mengandung konten mengecilkan arti pentingnya pemberian vaksinasi. ${ }^{34,36,37}$ Dalam beberapa penelitian internasional, beberapa faktor telah diidentifikasi mempengaruhi penerimaan terhadap vaksin, antara lain kurangnya pengetahuan tentang kebutuhan vaksin, kesalahan persepsi tentang vaksin dan penyakit yang dapat dicegah dengan vaksin, takut terhadap efek samping vaksinasi, ketersediaan vaksin yang tidak konsisten, kurangnya kepercayaan terhadap sistem kesehatan, dan riwayat negatif dengan program imunisasi sebelumnya. ${ }^{38}$

Internet merupakan platform yang tepat untuk mendukung dan memfasilitasi keputusan apakah akan melakukan vaksinasi atau tidak. ${ }^{39,40}$ Informasi saja kadang tidak cukup untuk menciptakan kesadaran dan acceptabilitas terhadap imunisasi, tetapi hasilnya lebih efektif jika didukung secara aktif oleh seluruh stakeholder. ${ }^{41,42}$ Internet tidak hanya dapat dimanfaatkan untuk advokasi terkait vaksinasi, ${ }^{43}$ tetapi juga bisa dimanfaatkan untuk meningkatkan pendidikan di kalangan petugas kesehatan, ${ }^{44}$ terutama di negara-negara berpenghasilan rendah dan menengah (LMICs). ${ }^{45}$ Penelitian yang dilakukan di Melbourne, Australia, mendapatkan hasil bahwa internet terbukti menjadi sarana yang efektif untuk meningkatkan partisipasi dan tingkat cakupan selama kampanye vaksinasi influenza. ${ }^{46}$

Internet memberikan kesempatan kepada para antivaksinasi untuk mendapatkan paparan informasi yang belum pernah terjadi sebelumnya. Di Amerika Serikat, sebanyak 55 persen orang dewasa dengan akses internet menggunakannya untuk mencari informasi terkait kesehatan. ${ }^{47}$ Internet memiliki potensi besar untuk menyebarluaskan informasi kesehatan yang tidak benar dan berpotensi berbahaya. ${ }^{36}$ Secara khusus, orang tua yang dihadapkan dengan keputusan untuk memvaksinasi anak-anak mereka atau tidak, maka besar kemungkinannya akan mencari informasi tentang vaksin melalui Internet terlebih dahulu daripada melalui dokter. ${ }^{48}$ Turunnya kepercayaan publik terhadap keamanan vaksin dan cakupan vaksin, digambarkan sebagai "krisis pada masa datang" khususnya di negara maju. ${ }^{15,49}$ Kebingungan publik dan keraguan terhadap vaksin campakgondok-rubella (MMR) disorot pada sebuah studi pada tahun 2010 di Kanada yang melaporkan bahwa 65 persen perempuan dan 72 persen laki-laki percaya bahwa vaksin itu tidak aman. ${ }^{50}$ Selain itu survei pada tahun 2015 mengungkapkan bahwa dua dari lima warga Kanada percaya bahwa "ilmu vaksinasi tidak cukup jelas". ${ }^{51}$

Para peneliti melaporkan perlunya komunitas kesehatan masyarakat untuk memiliki pemahaman yang lebih informatif tentang penggunaan internet, bagaimana dan sejauh mana interaksi media sosial dapat menjawab pertanyaan-pertanyaan tentang vaksin. Mengingat semakin populernya platform media sosial serta pengaruhnya terhadap imunisasi anak, perlu dipahami faktor-faktor apa yang mempengaruhi individu ketika membuat keputusan vaksinasi. Dalam hal imunisasi, keputusan untuk memberikan vaksinasi kepada anak, seimbang dengan risiko jika tidak diberikan yaitu tertular penyakit yang dapat dicegah dengan imunisasi. ${ }^{17}$ Dalam sebuah studi deskriptif singkat tentang konten situssitus antivaksinasi, Nasir (2000) mencatat bahwa 2 - 5 dari 10 "hit" pada masing-masing 4 mesin pencari (search engine) adalah situssitus antivaksinasi, menggunakan kata kunci "vaksinasi" dan "imunisasi". ${ }^{52}$ Studi yang dilakukan oleh Abbott (2000) menemukan bahwa ketika mencari informasi dengan kata kunci "vaksinasi MMR", sebesar 42,5 persen dari situs web yang dihasilkan oleh mesin pencarian berisi konten antivaksinasi, sebesar 32,5 persen mendukung vaksinasi, dan sebesar 25 persen mengandung konten netral. ${ }^{53}$ Studi yang dilakukan oleh Davies, Chapman, dan Leask (2002) menemukan bahwa penggunaan kata kunci "vaksinasi", sebanyak 43 persen dari 
10 situs pertama yang ditampilkan pada 7 mesin pencari adalah situs antivaksinasi, sedangkan penggunaan kata kunci "imunisasi" hanya 6 persen dari situs yang ditampilkan adalah situs antivaksinasi. ${ }^{36,54}$ Sayangnya, sampai sejauh ini di Indonesia belum ada penelitian yang melakukan studi tentang kehadiran internet dan era media sosial sekarang ini yang dapat mempengaruhi pilihan orangtua untuk memberikan vaksinasi pada anaknya atau tidak. Ponsel dan internet telah menjadi bagian hidup sehari-hari masyarakat Indonesia. Teknologi yang terus berkembang membuat jumlah pengguna internet di Indonesia juga semakin banyak. ${ }^{26}$ Terdapat bukti bahwa media sosial berdampak positif terhadap luasnya jangkauan pesan kesehatan masyarakat yang secara efektif meningkatkan kesadaran masyarakat, meningkatkan pengetahuan dan keterampilan, serta terjadinya perubahan perilaku. Penetrasi internet yang masih rendah memberikan peluang lebih luas bagi pemerintah Indonesia untuk melakukan ekspansi jaringan internet sampai ke seluruh pelosok Indonesia. Dengan demikian, semua informasi dapat lebih mudah tersampaikan ke seluruh lapisan masyarakat. Studi perubahan perilaku jelas menunjukkan pentingnya koneksi sosial untuk mendukung perubahan perilaku. ${ }^{55}$ Studi intervensi internet juga menunjukkan bahwa jaringan online mampu memfasilitasi penciptaan dan koneksi sosial melalui partisipasi langsung dalam mengelola masalah kesehatan. ${ }^{55,56}$ Dengan demikian, sangat mungkin penggunaan komunikasi media sosial dan pertukaran informasi yang fokusnya pada kesehatan memiliki dampak signifikan terhadap perilaku yang relevan dengan kesehatan masyarakat. ${ }^{14}$ Di sisi lain, perlu adanya dorongan kepada semua lapisan masyarakat agar memiliki etika bagaimana memanfaatkan media sosial. Penyebaran informasi tanpa dikoreksi maupun dipilah, pada akhirnya akan berdampak pada hukum dan informasi hoax yang dapat memecah belah publik. ${ }^{18}$

\section{KESIMPULAN}

Akses internet di keluarga Indonesia sebesar 46 persen, dan cakupan imunisasi lengkap anak bawah dua tahun adalah sebesar 65,3 persen. Terdapat hubungan yang bermakna antara akses internet di keluarga dengan status kelengkapan imunisasi anak bawah dua tahun (baduta) di Indonesia dengan Odds Ratio (OR) 1,37. Variabel jumlah balita dalam keluarga serta variable ibu melakukan pemeriksaan ANC K4 saat kehamilan, menjadi variabel perancu dalam penelitian ini. Internet dapat digunakan sebagai sumber pencarian informasi yang kaya tentang vaksin atau imunisasi.

\section{SARAN}

Perlu perluasan akses internet bagi seluruh penduduk Indonesia sampai daerah pelosok demi tercapainya pemerataan pembangunan terutama untuk kemudahan akses informasi. Konten-konten dari para stakeholder yang memberikan informasi tentang pentingnya pemberian imunisasi pada anak perlu lebih diperbanyak. Penelitian lebih lanjut tentang perilaku penduduk Indonesia pada penggunaan internet terhadap akses tentang kesehatan pada umumnya serta persepsi penerimaan imunisasi pada khususnya perlu untuk dilakukan.

\section{UCAPAN TERIMAKASIH}

Kami ucapkan terimakasih kepada Bridgette Wellington dari The Demographic and Health Surveys (DHS) program yang telah memfasilitasi penggunaan data Survei Demografi Kesehatan Indonesia tahun 2017. Seluruh penulis merupakan kontributor utama dalam penyusunan artikel ini.

\section{DAFTAR PUSTAKA}

1. Statistics Canada. Individual Internet use and e-commerce, 2012. Stat Canada [Internet]. 2013;2010-3. Available from: http://www.statcan.gc.ca/dailyquotidien/131028/dq131028aeng.pdf\%0Ahttp://www.statcan.gc.ca/d aily-quotidien/131028/dq131028aeng.htm

2. Mills E, Jadad AR, Ross C, Wilson K. Systematic review of qualitative studies exploring parental beliefs and attitudes toward childhood vaccination identifies common barriers to vaccination. J Clin Epidemiol [Internet]. 2005 Nov 1;58(11):1081-8. Available from: https://doi.org/10.1016/j.jclinepi.2005.0 9.002

3. Tonsaker T, Bartlett G, Trpkov C. Health information on the Internet. Can Fam Physician. 2014;60:407-8. 
4. Hinman AR, Orenstein WO, Schuchat A. Vaccine-Preventable Diseases, Immunizations, and MMWR 1961-2011 [Internet]. Atlanta; 2011. Available from:

https://www.cdc.gov/mmwr/preview/m mwrhtml/su6004a9.htm

5. Laxminarayan R, Ganguly NK. India' s Vaccine Deficit: Why More Than Half Of Indian Children Are Not Fully Immunized, And What Can-And Should-Be Done. Health Aff. 2011;6(6):1096-103.

6. Sugerman DE, Barskey AE, Delea MG, Ortega-Sanchez IR, Bi D, Ralston KJ, et al. Measles outbreak in a highly vaccinated population, San Diego, 2008: role of the intentionally undervaccinated. Pediatrics. 2010 Apr;125(4):747-55.

7. Schaetti C, Hutubessy R, Ali SM, Pach A, Weiss MG, Chaignat $C$, et al. Oral cholera vaccine use in Zanzibar: socioeconomic and behavioural features affecting demand and acceptance. Bio Med Cent. 2009;11:1-11.

8. Larson HJ, Brocard P, Garnett G. The India HPV-vaccine suspension. Lancet. 2010;376:9-10.

9. Golberg RM. Doctored truth, dead babies Fantasy vaccine fears go deeper than one fraudulent study [Internet]. Washington Post. 2011 [cited 2020 Jun 25]. Available from: https://www.washingtontimes.com/new s/2011/jan/13/doctored-truth-deadbabies/

10. Colgrove J, Bayer R. Could it happen here? Vaccine risk controversies and the specter of derailment. Health Aff (Millwood). 2005;24(3):729-39.

11. Stern M, Markel H. The History Of Vaccines And Immunization: Familiar Patterns, New Challenges. Heal Aff. 2005;24(1):611-21.

12. Kennedy A, Lavail K, Nowak G, Basket M, Landry S. Confidence About Vaccines In The United States: Understanding Parents ' Perceptions. Heal Aff. 2011;(June):1151-9.

13. Fox S. The Social Life of Health Information, 2011: Peer-to-peer Healthcare [Internet]. Washington: California HealthCare Foundation; 2011. Available from:
http://pewinternet.org/Reports/2011/So cial-Life-of-Health-Info/Part-3/Section1.aspx

14. Schein R, Wilson K, Keelan J. Literature Review On Effectiveness of the Use of Social Media a Report for Peel Public Health [Internet]. 2010 [cited 2020 Jun 24]. Available from: https://www.semanticscholar.org/paper /Literature-review-on-effectiveness-ofthe-use-of-a-Schein-

Wilson/f5011985741978662b1cbe229e e2e662551b17e8

15. Larson HJ, Cooper LZ, Eskola J, Katz SL, Ratzan S. New Decade of Vaccines 5 Addressing the vaccine confi dence gap. Lancet. 2011;378.

16. Kata A. A postmodern Pandora' $s$ box : Anti-vaccination misinformation on the Internet. Vaccine. 2010;28:1709-16.

17. Sanchez T, Ianos AC, Broniatowski D, Chandir S, Tustin JL. Internet exposure associated with canadian parents'perception of risk on childhood immunization: Cross-sectional study. J Med Internet Res. 2018;20(1).

18. Rahadi DR. Perilaku pengguna dan informasi Hoax di Media Sosial. J Manaj dan Kewirausahaan. 2017;5(1).

19. APJII. Potret jaman now pengguna dan perilaku internet Indonesia [Internet]. Buletin APJI. 2018. Available from: https://apjii.or.id/downfile/file/BULETI NAPJIIEDISI23April2018.pdf

20. Sulistiyani P, Shaluhiyah Z, Cahyo K. Gambaran Penolakan Masyarakat Terhadap Imunisasi Dasar Lengkap Bagi Balita (Studi Di Kelurahan Sendangmulyo, Kecamatan Tembalang, Kota Semarang). J Kesehat Masy. 2017;5(5):1081-91.

21. Kemenkes RI. Peraturan Menteri Kesehatan Republik Indonesia Nomor 12 tahun 2017 Tentang Penyelenggaraan Imunisasi. 2017.

22. Ahmad OB, Boschi-pinto C, Lopez AD. Age standardization of rates: a new WHO standard. GPE Discuss Pap Ser [Internet]. 2001;(31):1-14. Available from:

http://www.who.int/healthinfo/paper31. pdf

23. BKKBN. Peran Bkkbn Di Balik Gerakan Penanggulangan Stunting. J Kel [Internet]. 2018;1(1):44. Available 
from: https://www.bkkbn.go.id/pocontent/uploads/Final.JK.Edisi.Ketiga. 2017.Min.pdf

24. Dixit P, Dwivedi LK, Ram F. Strategies to Improve Child Immunization via Antenatal Care Visits in India: A Propensity Score Matching Analysis. PLoS One. 2013;8(6).

25. BKKBN, BPS, Kemenkes RI. Indonesian Demographic Health Survey. Statistics Indonesia, NPFPB, MOH, USAID. 2018.

26. Lestari KD. Perilaku Masyarakat Indonesia dalam Penggunaan Internet [Internet]. Institut Pertanian Bogor; 2014. Available from: https://repository.ipb.ac.id/bitstream/ha ndle/123456789/69135/G14kdl.pdf;seq uence $=1$

27. Bleier K. More Canadians Use Facebook Daily Than Anywhere Else in the World [Internet]. Financial Post. 2013 [cited 2020 Jul 5]. Available from: https://business.financialpost.com/tech nology/more-canadians-use-facebookdaily-than-anywhere-else-in-the-world

28. Faber H. Canadian Social Media Statistics 2013 [Internet]. Web Fuel. 2013 [cited 2020 Jul 5]. Available from: http://www.webfuel.ca/canadian-socialmedia-statistics-2013/

29. Harmsen IA, Doorman GG, Mollema L, Ruiter RAC, Kok G, Melker HE De. Parental information-seeking behaviour in childhood vaccinations. 2013;1-10.

30. Bianco A, Zucco R, Ella C, Nobile GA, Pileggi C, Pavia M. Parents Seeking Health-Related Information on the Internet : Cross-Sectional Study. J Med Internet Res. 2013;15(9).

31. Bragazzi NL, Barberis I, Rosselli R, Gianfredi V, Nucci D, Moretti M, et al. How often people google for vaccination: Qualitative and quantitative insights from a systematic search of the web-based activities using Google Trends. Hum Vaccines Immunother [Internet]. 2017;13(2):464-9. Available from: http://dx.doi.org/10.1080/21645515.20 17.1264742

32. Barak-corren Y, Group PM, Reis BY, Group PM. HHS Public Access. Vaccine. 2016;33(21):2395-8.

33. Piscaglia L. Internet and Social Media :
Influence on the parent' $\mathrm{s}$ vaccination decision [Internet]. University of Tennessee Health Science Center; 2016. Available from: https://dc.uthsc.edu/cgi/viewcontent.cgi ?article $=1001 \&$ context $=$ hiimappliedres earch

34. Guidry JPD, Carlyle K, Messner M, Jin Y. On pins and needles: how vaccines are portrayed on Pinterest. Vaccine. 2015 Sep;33(39):5051-6.

35. Chatterjee A. Vaccine and immunization resources on the World Wide Web. Clin Infect Dis an Off Publ Infect Dis Soc Am. 2003 Feb;36(3):355-62.

36. Davies P, Chapman S, Leask J. Antivaccination activists on the world wide web. Arch Dis Child. 2006;22-5.

37. Tafuri S, Gallone MS, Gallone MF, Zorico I, Aiello V, Germinario C. Communication about vaccinations in Italian websites A quantitative analysis. Hum Vaccines Immunother. 2014;10(5):1416-20.

38. Handy LK, Maroudi S, Powell M, Nfila B, Moser C, Japa I, et al. The impact of access to immunization information on vaccine acceptance in three countries. PLoS One. 2017;12(8):1-16.

39. Connolly T, Reb J. Toward interactive, Internet-based decision aid for vaccination decisions: better information alone is not enough. Vaccine. 2012 May;30(25):3813-8.

40. Pineda D, Myers MG. Finding reliable information about vaccines. Pediatrics. 2011 May;127 Suppl:S134-7.

41. Thomson A, Robinson K, Valléetourangeau G. The 5As: A practical taxonomy for the determinants of vaccine uptake. Vaccine [Internet]. 2016;34(8):1018-24. Available from: http://dx.doi.org/10.1016/j.vaccine. 201 5.11.065

42. Glanz JM, Kraus CR, Daley MF. Addressing Parental Vaccine Concerns : Engagement, Balance, and Timing. Plos Biol. 2015;1-8.

43. Signorelli C, Odone A. Advocacy communication, vaccines and the role of scientific societies. Ann Ig. 2015;27(5):737-47.

44. Thielmann A, Viehmann A, Weltermann BM. Effectiveness of a 
web-based education program to improve vaccine storage conditions in primary care ( Keep Cool ): study protocol for a randomized controlled trial. Trials [Internet]. 2015;1-8. Available from: http://dx.doi.org/10.1186/s13063-0150824-9

45. Company A, Bosch FX, Sanjosé S De. Training in the prevention of cervical cancer: advantages of e-learning. ecancer. 2015;9:1-10.

46. Mccarthy EA, Pollock WE, Tapper L, Sommerville M, Mcdonald S. Increasing uptake of influenza vaccine by pregnant women post H1N1 pandemic: a longitudinal study in Melbourne , Australia , 2010 to 2014. BMC. 2015;1-7.

47. Fox S, Rainie L, Horrigan J, Lenhart A, Spooner T, Burke M, et al. The online health care revolution: How the Web helps Americans take better care of themselves. 1999.

48. Downs JS, de Bruin WB, Fischhoff B. Parents' vaccination comprehension and decisions. Vaccine. 2008 Mar;26(12):1595-607.

49. Larson HJ. Negotiating vaccine acceptance in an era of reluctance. Hum Vaccin. 2013;9(August):1779-81.

50. Seeman N, Seeman M. Autism and the Measles, Mumps, and Rubella Vaccine: Need to Communicate a Health Study
Retraction to Patients [Internet]. Society for Participatory Medicine. 2010 [cited 2020 Jul 9]. Available from: https://participatorymedicine.org/journa 1/evidence/research/2010/12/17/autismand-the-measles-mumps-and-rubellavaccine-need-to-communicate-a-healthstudy-retraction-to-patients/

51. Downs JS, Bruin WB de, Fischhoff B. Parents Vaccination comprehension and decision. Vaccine [Internet]. 2008 [cited 2020 Jun 23];26(12). Available from: http://angusreid.org/vaccines/

52. Nasir L. Reconnoitering the antivaccination web sites: news from the front. J Fam Pract. 2000 Aug;49(8):731-3.

53. Abbott VP. Web page quality: can we measure it and what do we find? A report of exploratory findings. J Public Health Med. 2000;22(2):191-7.

54. Wolfe RM, Sharp LK. Vaccination or Immunization? The Impact of Search Terms on the Internet. $\mathbf{J}$ Health Commun. 2005;(Cdc):539-53.

55. Luke DA, Harris JK. Network Analysis in Public Health: History, Methods, and Applications. Annu Rev Public Health. 2007;28:69-73.

56. Idriss SZ, Kvedar JC, Watson AJ. The role of online support communities: benefits of expanded social networks to patients with psoriasis. Arch Dermatol. 2009 Jan;145(1):46-51. 